„Bohemistyka” 2019, nr 2, ISSN 1642-9893

Ivana DOBROTOVÁ

DOI: $10.14746 /$ bo.2019.2.6

Uniwersytet Palackiego w Ołomuńcu

\section{Dyskurs w komentarzach politycznych polskich i czeskich dyskusji w Internecie na przykładzie problemu migracji}

Keywords: Czech language, Polish language, discourse, migration, corpus analysis Słowa kluczowe: język czeski, język polski, dyskurs, migracja, analiza korpusowa

\section{Abstract}

A paper is focusing on discourse analysis of Czech and Polish internet discussions after case of Aquarius ship in June 2018. Author is using discourse analysis to merge all comments in one heterogenic text and to show how discussion about migration looks like in case of most Eurosceptic society of Eastern Europe (Czech Republic) and in most Eurooptimist society (Poland). Discourse analysis together with tools of quantitative analysis (software AnrConc) shows that despite differences between Czechs and Poles, both nations feels themselves as part of European community. It was shown as well, that in both nations there is strong need to find irrational explanations of migrant crisis.

W artykule autorka analizuje dyskurs czeskich i polskich forów internetowych po wypadku statku Aquarius w czerwcu 2018 r. Wykorzystuje metodę analizy, aby połączyć wszystkie komentarze w jeden heterogeniczny tekst i pokazać, jak wygląda dyskusja na temat migracji w większości społeczeństwa eurosceptycznego Europy Wschodniej (Republika Czeska) i w większości społeczeństwa eurooptymistycznego (Polska). Analiza dyskursu wraz z analizą frekwencyjną (oprogramowanie AnrConc) pokazuje, że pomimo różnic między Czechami i Polakami oba narody czują się częścią społeczności europejskiej. Pokazano również, że w obu krajach istnieje silna potrzeba znalezienia irracjonalnych wyjaśnień kryzysu migracyjnego.

\section{Wstęp}

Na bliską zależność pomiędzy pojęciami tekstu i dyskursu zwracano uwage zarówno w polskim, jak i czeskim językoznawstwie. Pokrewność obu pojęć podkreśla przykładowo Svobodová, która za Hoff- manovą mówi wręcz o synonimiczności tych pojęć w niektórych sytuacjach (Svobodová 2016, s. 15). Przyjmując jednak perspektywę wypracowaną w ramach krytycznej analizy dyskursu można stwierdzić, że w niektórych sytuacjach komunikacyjnych, z którymi możemy spotkać się w dzisiejszym świecie niemal na każdym kroku, pojęcie dyskursu pozwala nam rozszerzyć horyzont badawczy związany z tekstem. Jeśli przyjąć założenie, że dyskurs jest strukturą poszerzającą dotychczasowe rozumienie tekstu jako skończonego komunikatu. Rozszerzenie go o kontekst społeczny, czyli spojrzenie na dyskurs jako zdarzenie komunikacyjne, jak to ujmuje T. van Dijk (2001, s. 10) sprawia, że jako całość badawczą możemy uznawać komunikaty złożone z wielu jednostek, to zaś otwiera drogę do większego wykorzystania narzędzi statystycznych w językoznawstwie. I chociaż narzędzia tego typu były wykorzystywane już od dość dawna (najlepszym tego przykładem może być polski Słownik frekwencyjny polszczyzny współczesnej - bodaj pierwsza praca językoznawcza tak dalece wykorzystująca techniki komputerowe), to dopiero rozwój lingwistyki korpusowej pokazał, jakie korzyści można odnieść z analizy materiału tekstowego pod względem ilościowym przekraczającego możliwości czytelnicze pojedynczego badacza.

Pojęcie tekstu w wyniku prac van Dijka i jego następców uległo zatem rozszerzeniu - tekstem może być kompilacja różnych wypowiedzi traktowanych dzięki pojęciu dyskursu jako jedna całość. Narzędzia komputerowe i lingwistyka korpusowa dały z kolei narzędzia do opracowywania dużych partii tekstu. W niniejszym artykule chciałam postawić z kolei pytanie, czy z faktów tych wynika coś dla językoznawczych badań kontrastywnych. $Z$ racji moich zainteresowań badawczych łączących problemy polonistyczne $\mathrm{z}$ bohemistycznymi, chciałabym sprawdzić, czy połączenie podejścia dyskursywnego z narzędziami językoznawczej analizy ilościowej korzystającej z narzędzi komputerowych może odsłaniać jakieś nowe informacje dotyczące użycia równocześnie dwóch systemów językowych - czeszczyzny i polszczyzny. 
Jakiekolwiek badania muszą jednak zostać poprzedzone kilkoma zastrzeżeniami dotyczącymi samego pojęcia dyskursu. Z perspektywy językoznawczej termin ten jawi się w chwili obecnej jako stosunkowo mało użyteczny, ze względu na różnorodność kontekstów w jakich się pojawia. Jak zauważa bowiem wybitny polski socjolog „słowo dyskurs zrobiło we współczesnej humanistyce oszałamiająca karierę, [to] coraz trudniej o pewność, czy w ogóle jeszcze cokolwiek znaczy, używa się go bowiem na wiele różnych sposobów, a całkiem nierzadko po prostu jako uczonego określenia dowolnej dłuższej wypowiedzi lub dowolnego tekstu" (Szacki 2005, s. 905)

Teksty zamieszczone w syntetyzującym zbiorze Dyskurs i jego odmiany (2016) zdają się sugerować, że polskie językoznawstwo pod pojęciem dyskursu chce widzieć swego rodzaju uniwersum tekstowe (przeglądu polskich badań nad dyskursem dokonała w osobnym artykule Bożena Witosz (2012), rozumiane najszerzej jak to tylko możliwe. Autorki tego tomu zdecydowały się na wydzielenie dyskursów instytucjonalnych, dyskursów wspólnotowych (ideologicznych, etnicznych i kulturowych) i wreszcie dyskursów medialnych. Znamienne jest przy tym, że samym pojęciem dyskursu zajmują się teksty zamieszczone dopiero w zakończeniu tomu, jak gdyby sugerowały, że nie ma sensu na wstępie wytyczać granic pojęciowych związanych z dyskursem, bowiem jak same zaznaczają we wstępie dyskurs, ze względu na swą heterogeniczną złożoność, otwartość i „mgławicowość”, zdaje się dziś najlepiej spełniać funkcję kategorii reprezentującej niestabilność świata społecznych relacji (Dyskurs... 2016, s. 9).

W takiej sytuacji trudno oczywiście mieć jakąkolwiek nadzieję na to, że pojęcie dyskursu uda się jeszcze kiedyś jednoznacznie zdefiniować. W niniejszym tekście chciałbym jednak pokazać, że pojęcie dyskursu w rozumieniu, jakie nadał mu pierwotnie T. van Dijk, który chciał w zjawisku tym widzieć współdziałanie trzech różnych płaszczyzn: użycia języka, przekazywania idei i interakcji w sytuacjach społecznych, zaś w analizie dyskursu upatrywał narzędzia ,dostarczającego opisu tych trzech wymiarów komunikacji” (van Dijk 2001, s. 10). Ważne też są dla mnie spostrzeżenia niemieckich językoznaw- ców, głównie W. Heinemanna, na które zwraca uwagę Janina Labocha, a czyni to - co warto podkreślić - w kontekście badań dyskursu polsko-czeskich dotyczących Zaolzia (Labocha 2016). Heinemann konstatuje mianowicie, że w uzupełniającej się relacji łączącej lingwistykę tekstu z lingwistyką dyskursu, lingwistykę tekstu należy traktować jako dyscyplinę podstawową. Dyskurs nie jest bowiem bezpośrednio, materialnie obecny w komunikacji językowej - jest uchwytny tylko pośrednio przez teksty i wypowiedzi (Labocha 2016, s. 157).

Zastrzeżenie Heinemanna przytoczone przez J. Labochę wypada widzieć jako próbę wyznaczenia granic tego, czym może zajmować się językoznawstwo i podzielam je. Bez generowanego pisemnie lub ustnie tekstu nie ma przedmiotu badań językoznawczych. W niniejszym artykule materiału do analizy dostarczą mi komentarze związane ze społecznie kontrowersyjną problematyką migracji. Wybór ten dyktowany jest założeniem, że tylko tematy społecznie dyskutowane są w stanie dostarczyć wystarczającej ilości przedmiotu badawczego, do tego by celowe było wykorzystanie komputerowych narzędzi analizy korpusowej.

\section{Faktograficzne tlo sytuacji komunikacyjnej}

W czerwcu 2018 roku pojawił się cały szereg informacji związanych pośrednio lub bezpośrednio z problemem migracji, co wiązało się z licznymi wydarzeniami politycznymi, które wokół tego tematu się rozgrywały. Ilość wydarzeń politycznych przekładała się, co zrozumiałe, na ilość materiałów medialnych relacjonujących je. Doniesienia medialne $\mathrm{z}$ kolei prowokowały do dyskusji na ich temat. Z politycznych okoliczności, które z tą problematyką się łączyły w ostatnim czasie wystarczy wymienić choćby mini-szczyt unijny poświęcony problematyce migracji $\mathrm{z}$ pierwszej połowy czerwca, który w przestrzeni medialnej pojawił się przede wszystkim ze względu na fakt, że ani przedstawiciele czeskich ani polskich władz nie zdecydowali się w nim wziąć udziału. Kolejnym wydarzeniem był szczyt Unii Europe- 
jskiej w Brukseli, na którym podejmowane były decyzje dotyczące polityki migracyjnej całej Unii Europejskiej.

\section{Cele badawcze}

W niniejszym tekście chciałabym skupić swą uwagę tylko na trzecim wydarzeniu, mianowicie na historii statku Aquarius, który z kilkuset osobami na pokładzie - głównie kobietami i dziećmi - nie uzyskał przez kilka dni pozwolenia na zacumowanie w portach włoskich. Dostępu do swego wybrzeża odmówiła statkowi również Malta, co zaczęło zagrażać znajdującym się na pokładzie uchodźcom. Wydarzenia związane $\mathrm{z}$ odmową przyjęcia migrantów były relacjonowane przez wszystkie media - zarówno w Polsce, jak i w Czechach - przez kilka kolejnych dni: od 10 do 17 czerwca i wzbudziły duże zainteresowanie wśród czytelników.

Ponieważ celem badawczym niniejszego tekstu jest sprawdzenie, czy narzędzia analizy dyskursu mogą być przydatne w analizie kontrastywnej czesko-polskiej oraz czy ich zastosowanie może być pomocne w odsłanianiu zjawisk językowych, zdecydowałam się poddać analizie wszystkie komentarze do tekstów odredakcyjnych poświęconych temu właśnie wydarzeniu, upublicznionych za pomoca serwisów informacyjnych Idnes.cz i Gazeta.pl. Chodzi o strony znajdujące się w odpowiadających sobie krajach w czołówkach najpopularniejszych serwisów dostarczających informacji ze świata. Serwis idnes.cz ocenia się jako 6 najpopularniejszy w Czechach (https://www.markomu.cz/nejnavstevovanejsi-weby; dostęp: 04.07.2018), zaś serwisy grupy gazeta.pl zajęły ósme miejsce $\mathrm{w}$ analogicznym rankingu stron www w Polsce (https://www.wirtualnemedia.pl/artykul/najpopular niejsze-portale-internetowe-w-polsce-kwiecien-2018; dostęp: 04.07. 2018). Wybór ten był również podyktowany założeniem, że tylko duże serwisy informacyjne gwarantują wystarczającą ilość komentarzy składających się na materiał tekstowy.

\section{Charakterystyka materiału tekstowego}

Materiał zbierany był prostym sposobem. Artykuły zostały wybrane w oparciu o wyszukiwanie nazwy Aquarius, czyli nazwy łodzi, na której znaleźli się migranci z Afryki. Każdy artykuł skopiowano, a nastepnie skopiowane zostały wszystkie komentarze. W wypadku materiałów czeskich zastosowano wyświetlenie wszystkich komentarzy według wątków tematycznych, co pozwoliło utrzymać konwencję dialogu w tych miejscach, w których się ona pojawiała. W wypadku tekstu polskiego opcja automatycznego układania tekstów komentarzy według wątków tematycznych nie jest przewidziana w systemie, w związku z czym rozwinięto ręcznie wszystkie wątki i dopiero wówczas dokonano skopiowania tekstu. Celem kopiowania było przede wszystkim zarchiwizowanie całego materiału, ale również dostosowanie go do wymagań programów wykorzystanych w analizie korpusowej, do czego jeszcze wrócimy przy okazji dalszych rozważań.

W powyższy sposób udało zebrać się stosunkowo obszerny materiał tekstowy obejmujący w wersji czeskiej 271 stron, zaś w wersji polskiej 52 strony. Widać więc wyraźną dysproporcję w zebranym na podstawie tych samych kryteriów materiale tekstowym, choć zaznaczyć wypada dwie okoliczności, które niewątpliwie miały wpływ na powstanie tej dysproporcji. Po pierwsze w serwisie gazeta.pl w badanym okresie ukazał się o jeden materiał redakcyjny mniej niż w wypadku serwisu czeskiego. Po drugie w przypadku jednego z tekstów polskich redakcja serwisu wyłączyła możliwość komentowania. Praktyka ta była przez wydawce portalu gazeta.pl stosowana już wcześniej jako próba uniknięcia łamania regulaminu serwisu. Artykuły o uchodźcach, które pojawiały się w latach 2015 i 2016 wywoływały dużą ilość wulgarnych wypowiedzi ze strony komentujących. W wypadkach późniejszych tekstów pojawiała się informacja mówiąca, że „Z powodu wyjątkowo agresywnych treści, zamykamy możliwość komentowania pod naszymi tekstami o uchodźcach" (por. Http://www. otwarta.org/agora-zamyka-fora-pod-tekstami-o-uchodzcach; dostep: 04.07.2018). Należy jednak zwrócić uwagę, że w wypadku analizo- 
wanego przeze mnie tekstu taka informacja odredakcyjna nie pojawiła się, trudno więc ustalić, jakie były powody ograniczenia przestrzeni dyskursywnej w tym wypadku. Niezależnie jednak od przyczyny należy przyjąć, że komentarze czeskie są wynikiem dyskusji dotyczącej dwukrotnie większej ilości tekstów niż w wypadku tekstów polskich. Nawet jednak potencjalne podwojenie ilości polskiego materiału tekstowego i tak nie prowadziłoby do równowagi między komentarzami czeskimi i polskimi, z czego można wyciągnąć wniosek, że ten konkretny temat był dla czeskich dyskutantów bardziej atrakcyjny niż dla polskich.

Czy wprowadzane przez nadawców masowych zmiany dotyczące zamieszczania komentarzy mają konsekwencje z perspektywy językoznawczej? Jeśli idzie o kwestie analizy dyskursu, należy odpowiedzieć, że z całą pewnością tak właśnie jest. Dobrze dokumentuje to przypadek portalu informacyjnego gazeta.pl, który jest powiązany z ukazującym się zarówno w wersji drukowanej, jak i internetowej dziennikiem Gazeta Wyborcza (wersja internetowa to serwis wyborcza.pl). W serwisie gazeta.pl pojawiają się więc niektóre publikacje wcześniej opublikowane w ramach Gazety Wyborczej, co sprawia, że pod względem identyfikacji nadawcy zbiorowego można uznać oba media za tożsame. Stosują one jednak inną politykę dopuszczania osób do pozostawienia komentarzy. Portal gazeta.pl jak już wspomniałam umożliwia komentowanie wszystkim tym, którzy zalogują się, bądź przy użyciu danych dostępowych w obrębie samego serwisu, bądź też przy użyciu danych sieci społecznościowych. Oznacza to w praktyce, że każda osoba posiadająca konto na Facebooku czy w ramach portalu gazeta.pl może pozostawiać komentarze. W wypadku serwisu Wyborcza.pl mamy do czynienia z wyraźnym ograniczeniem możliwości komentowania - do wypowiadania się w komentarzach uprawnione są wyłącznie osoby opłacające prenumeratę „Gazety Wyborczej”. Konieczność wnoszenia opłaty wpływa na ilość osób uczestniczących w dyskusji, a co za tym idzie na ilość nadawców, którzy uczestniczą w danym dyskursie medialnym. Do zagadnienia tego wypadnie mi jeszcze wrócić omawiając je na konkretnym przykładzie.
Tu zaznaczmy jeszcze tylko, że stopniowe ograniczanie możliwości pozostawiania komentarzy, a w skrajnych wypadkach całkowita rezygnacja redakcji z opcji komentowania artykułów prowadzi do sytuacji, w której język Internetu upodabnia się do innych - bardziej tradycyjnych - form komunikacji masowej, w której proces komunikowania przebiegał w zasadzie jednokierunkowo, choć w badaniach medioznawczych i na ten temat toczone są już od dłuższego czasu dyskusje (por. Goban-Klas 2004, s. 44). Bez względu jednak na spory medioznawców wypada zauważyć, że ewentualne zniknięcie komentarzy z serwisów internetowych wpłynie na możliwości przeprowadzania takich analiz, jak te, które legły u podstaw niniejszego artykułu.

Zebrany materiał tekstowy postanowiłam traktować jako jeden, heterogeniczny, ale spójny, tekst. W tym upatruję główną zmianę, jaką przynosi dyskursywne spojrzenie na użycie języka w Internecie. Nie da bowiem ukryć się, że na całość materiału tekstowego złożyło się łącznie około 4000 różnych wypowiedzi nie tylko różnych, ale i różnorodnych autorów. Część z nich pozostawała bowiem zinstytucjonalizowana - niektóre artykuły serwisów informacyjnych nie posiadały atrybucji. Niektóre teksty były z kolei autorskimi artykułami, które znalazły się również w drukowanych wersjach gazet. Jeśli zaś idzie o komentarze, to teoretycznie wszyscy uczestnicy dyskusji musieli się identyfikować, ale zazwyczaj dane konkretnej osoby znane były tylko zinstytucjonalizowanemu nadawcy, który i tak nie brał udziału w dyskusji. W tradycyjnie rozumianej lingwistyce tak powstały tekst nie mógłby być traktowany jako spójna całość. Analiza dyskursu oferuje taką właśnie możliwość - pozwala spojrzeć całościowo na dyskusję jako lingwistyczne zjawisko wymagające interakcji setek osób, dzięki czemu otrzymany materiał tekstowy może stracić cechy indywidualne, a odsłonić wiedzę natury bardziej ogólnej.

Oba serwisy informacje o tym wydarzeniu zamieszczały w rubryce wydarzenia/ świat, co oznacza, że w obu wypadkach użytkownicy mieli niemal identyczny dostęp do prezentowanych wiadomości. Oba serwisy umożliwiają również komentowanie swoich artykułów na podobnych zasadach. Możliwość taka jest dostępna dla wszystkich zalo- 
gowanych użytkowników, przy czym logowanie to wymaga podania adresu mailowego i hasła lub też skorzystania $z$ danych dostępnych przez media społecznościowe takie jak Facebook (idnes.cz i gazeta.pl) czy google.com (gazeta.pl). W wypadku obu serwisów możliwe jest również zalogowanie się przez konto stworzone w obrębie samych serwisów.

Pierwszym narzędziem, pozwalającym choćby w przybliżeniu podpowiedzieć na pytanie o to jak i o czym dyskutują czescy i polscy internauci, jest semantyczna analiza statystyczna $\mathrm{z}$ wykorzystaniem narzędzi wykorzystywanych w pracach korpusowych. Na użytek niniejszego tekstu do przeprowadzenia tej analizy wykorzystałam program AntConc. Materiał tekstowy poddany obróbce przy użyciu tego oprogramowania obejmował wyłącznie teksty komentarzy, poddany wcześniejszemu przygotowaniu redakcyjnemu (konwersja pliku typu .doc do formy .txt z wykorzystaniem kodowania znaków w systemie ASCII z dozwoloną substytucją znaków - takie postępowanie doprowadziło do zniknięcia czeskich znaków diakrytycznych, co jednak na ogólne wnioski nie ma najmniejszego wpływu).

\section{Analiza czeskiego materiału tekstowego}

Pierwszym krokiem w analizie statystycznej było stworzenie listy słów. Objęła ona 14440 pozycji. Po odrzuceniu przyimków, spójników, zaimków i partykuł (zajmujących z oczywistych względów pierwsze 20 pozycji) okazało się, że pierwszym znaczącym leksemem na liście był skrótowiec $E U$ na pozycji 34. Dalsze znaczace wyrazy pojawiły się na pozycjach 40 (lod), 41 (lide), 44 (italie), 50 (evropa) 58 (migranti), 78 (afrika). Sytuacja ta generalnie nie zmieniła się po zastosowaniu listy lemmatycznej.

Lista lemmatyczna $\mathrm{w}$ tradycyjnie rozumianej lingwistyce korpusowej stosowana jest często jako jedno z narzędzi pozwalających tworzyć relewantne listy słów - w tym sensie wspólnie z tzw. stop-listami odpowiadają za redukowanie wyników wyświetlanych w ramach pracy z tekstem poprzez filtrowanie wyników wyszukiwania przeprowadzonych przez maszynę (Gries 2009, s. 13). O ile jednak stop-listy po- zwalają na filtrację tego, co określiłam w poprzednim akapicie jako przyimki, spójniki, zaimki i partykuły, o tyle lista lemmatyczna pozwala na grupowanie wyników wyszukiwania w większe całości. Jej prymarnym celem jest rozwiązywanie problemów jakich komputerowej analizie tekstu nastręczają takie kwestie gramatyczne jak na przykład formy supletywne.

W wypadku analizowanych tekstów komentarza lista lemmatyczna została stworzona nie tylko do ujednolicenia form supletywnych i fleksyjnych, ale również jako narzędzie

Poniżej prezentuję zastosowaną przeze mnie listę lemmatyczna brak diakrytyki wynika ze specyfiki użytego do analizy korpusowej oprogramowania:

migranti $\rightarrow$ [migrantu] [migranty] [migranti] [migrace] [migraci] [migracni] [imigranty] [migrnatum]

lod $\rightarrow$ [lod] [lodi] [lode]

evropa $\rightarrow$ [evropa] [evrope] [evropske] [evropu] [evropskych] [evropy] [eu] [unie]

italie $\quad \rightarrow$ [italska] [italie] [itali] [italske] [italove] [italskeho] [italskych]

paseraci $\rightarrow$ [paseraci] [paseraku] [paseraky] [paserakum]

neziskovky $\rightarrow$ [neziskovky] [neziskovki] [neziskovek] [ziskovky] [nieziskovka] [charita] [neziskove] [organizace]

nemecko $\rightarrow$ [nemecko] [nemecku] [merkel] [merkelova]

uprchlici $\rightarrow$ [uprchlici] [uprchliku]

zachranit $\rightarrow$ [zachraneni] [zachranili] [zachranene] [zachranovat] [zachranila]

afrika $\rightarrow$ [afrika] [africane] [africany] [afriky] [africe]

cechy $\rightarrow$ ceska] [ceske] [ceskeho] [ceskem] [cesko] [ceskomoravskem] [ceskoslovenska] [ceskou] [cesku] [cesky] [ceskych] [ceskymi] [cr]

my

$\rightarrow$ [my] [nas] [nase] [nasemu] [nasi] [nasich] [nam]

Jak już wspomniałam jest ona stworzona nie tyle z myślą o ujednoliceniach wynikajacych ze specyfiki języka fleksyjnego, jakim jest język czeski, ale raczej z myślą o tworzeniu szeroko rozumianych pól semantycznych, które manifestują się w materiale tekstowym. Widać to szczególnie jasno w wypadku lemm nemecko i evropa, ale również w przypadku lemmy migranti, która łaczy pojęcia imigranta i migranta w całość tekstową wbrew logice leksyki czy słownika. 
Pełna stop-lista obejmowała w badaniu następujące jednostki: $a$, aby, ale, ani, by, co, d, do, facebook, foto, i, jak, jako, jan, je, jen, Jiř́, jsou, $k, k d y \check{z}, m a, n a, n e, o$, petr, pro, s, se, si, tak, tam, to, u, už, v, václav, $z, z a$, ze. Jak widać część z pominiętych jednostek zawdzięcza swoje miejsce na liście frekwencyjnej systemowi językowemu. Pojawienie się innych z kolei wynikało z zastosowanych metod zbierania i obróbki materiału tekstowego. Tak rzecz się ma z imionami - pojawiały się one jako dane identyfikujące uczestników dyskusji, stąd też ich pominięcie w analizie wyników.

Po zastosowaniu tych obu narzędzi wyniki analizy korpusowej jasno wskazuja, że dyskusja dotyczaca odredakcyjnego artykułu dotyczącego łodzi „Aquarius” tylko częściowo dotyczyła samej łodzi czy też problemu migracji w ogóle. Pięć najwyższych wyników prezentowało się po dokonaniu analizy następująco:

Evropa - rank: 1, freq. 605

Lod - rank 2, freq. 398

Migranti rank 3, freq. 388

Italie rank 4, freq. 314

Afrika rank 5, freq. 27

Cztery z nich należy w oczywisty sposób potraktować jako dowód na to, że uczestnicy dyskusji starali się cały prowadzony dyskurs traktować jako merytoryczny, choć z drugiej strony nie należy przy owej merytoryczności dać się ponieść nadmiernemu optymizmowi. Całość materiału tekstowego obejmowała bowiem ponad 3000 komentarzy tylko do jednego z tekstów odredakcyjnych dopisano owych komentarzy ponad 1700 . Czy zatem 605 trafień na sporządzonej liście to dużo czy mało? Wydaje się, że 5\% miara relewancji w dyskusji ujawniająca się na płaszczyźnie semantycznej potwierdza stereotyp głoszący, że przestrzeń internetowych dyskusji trudno uznać za nadmiernie merytoryczną.

Co jednak w tym zestawieniu rzuca się najbardziej w oczy, to fakt, że dyskusja o migracji przekształca się w rzeczywistości w dyskusję o Europie. Biorac pod uwagę fakt, że Czesi jako społeczeństwo sa postrzegani jako grupa raczej sceptyczna względem europejskiej inte- gracji, wynik taki zaskakuje. Uzyskane w trakcie badania konkordancje dla lemmy [evropa] wykazują raczej różnorakie troski dotyczące obecnej kondycji naszego kontynentu niż tylko wrogi stosunek do świata zewnętrznego i do Unii Europejskiej.

W komentarzach Europa jawi się jako miejsce borykające się z różnorakimi problemami, jak na przykład przeludnienie:

[1] Pritom Afrika ma mensi hustotu zalidneni nez Evropa. Cim to je, ze vsichni chteji bydlet natesnani jak sardinky.

[2] Pokud nekdo rozhodne, ze uz je Evropa naplnena, jak se zastavi dalsi proud migrantu?

[3] Myslim, ze Evropa z tohoto hlediska praska ve svech daleko vice nezli Afrika.

czy też problemy ekonomiczne:

[4] A kdyz toho nejsou schopni, tak si myslim, ze Evropa ma dostatecne ekonomicke paky, aby to chapali;

[5] Evropa na to nema ani financne, ani kapacitne.

Jasne też jest, że w opinii uczestniczących w dyskusji Europa nie jest wcale tak idealnym miejscem do życia:

[6] Treba o tom, ze Evropa neni zadna zeme zaslibena, ze budou dlouho cekat na papiry, muset se ucit jazyky, prizpusobovat se kulturam, ktere jsou jim cizi a hlavne ze budou mit velky problem najit praci.

[7] Cim vic jim budeme pomahat, tim vic bude silit jejich presvedceni, ze Evropa je raj, kde litaji peceni holubi do ust a proc tedy cekat, co nam sem Evropani dodaji, kdyz se muzeme presunout primo ke zdroji,

[8] Takze aby jim nejaka ziskovka (i kdyby k tomu byla ochotna, ono je to v rozporu se zajmy takove neziskovky) vykladala, ze Evropa neni takovy raj, jak si predstavuji, postrada smysl,

Co jest istotne w tym zestawieniu dla mnie, to przede wszystkim fakt, że czescy uczestnicy dyskusji o migracji - przynajmniej ci, którzy decydują się na w miarę merytoryczną dyskusję - skupiają się przede wszystkim na problemach Europy, nie zaś samych Czech.

Same Czechy w wyniku naszej analizy pojawiły się jako temat na dwa różne sposoby. Sposób pierwszy wiązał się z powierzchniowymi 
wyznacznikami semantycznymi, które zostały przeze mnie połączone w jedną całość lemmatyczną zaprezentowaną powyżej i obejmującą 13 różnych form językowych. Republika Czeska rozumiana jako podmiot działań związanych z kryzysem migracyjnym, pojawiła się w zestawieniu frekwencyjnym dopiero na 34 miejscu, za Włochami (których dotyczył tekst), Libią i Niemcami. Można by z tego wyciągnąć wniosek, że problem migracji nie jest problemem Czech jako państwa, ale raczej Czechów jako wspólnoty. Taką konstatację potwierdza pojawienie się na 6 miejscu listy frekwencyjnej połączonych w jedną lemmę odwołań do różnych typów zaimków związanych gramatycznie rzecz ująwszy z pierwszą osobą liczby mnogiej. W ten sposób możliwe było wyselekcjonowanie z całego materiału tekstowego tych wypowiedzi, które w ten czy inny sposób odwoływały się do wspólnoty.

Owa zbiorowość w większości wypadków widzi samą siebie jako część wspólnoty europejskiej:

[9] Ale take meli brutalni technologickou (zbranovou) prevahu. Dnes mame zbranovou prevahu stale my v Evrope a bojime se ji pouzit byt jen $\mathrm{k}$ prosazeni navratu migrantu odkud prisli.

[10] Obyvatele Evropy, kteri si tu po staleti budovali svuj zivotni prostor, naprosto nezajima, jak si svuj zivotni prostor zaridili jinde. My musime branit to, co zde mame, jinak skoncime vsichni stejne jako migranti.

[11] vsichni chteji do Evropy a jeste nam nekteri lide nadavaji, ze kdyz je nechceme, tak my jsme ti spatni.

W innych przypadkach chodzi nawet o wspólnotę szerszego charakteru - wszystkich mieszkańców planety:

[12] Je nas 7 miliard. Planeta rozumne „utahne“ tak 4 . Nekdo musi „z kola ven“ a my si musime rozmyslet zda to budeme my a nebo oni.

W większości wypadków chodzi jednak o członków wspólnoty, którzy mają poczucie działania w osamotnieniu:

[13] My ty zadky zvednout musime, abychom zaplatili dane a podporili rodinu a deti. Nam nikdo nic zadarmo neda.
[14] Jde o zivoty nase a nasich deti! Pokud je sem pustime budeme potrebovat zachranit my,ale nikdo nas nezachrani !!

Kryzys migracyjny nie jest zatem wyłącznie kryzysem związanym z napływem uchodźców czy migrantów ekonomicznych, ale jest również kryzysem zaufania wspólnoty do rozwiązań, które w jej imieniu znajdują politycy.

W tym sensie wyniki analizy korpusowej są nieco zaskakujące. Można je oczywiście thumaczyć tym, że dyskusja owa pokazuje, dlaczego Czesi niechętnie patrzą na Europę. Byłoby to jednak - jak się wydaje - duże uproszczenie, o czym świadczą wypowiedzi obnażające swoisty mit Europy dostatniej. Europa dla Czechów nie jest rajem, co świadczy o w miarę racjonalnym i trzeźwym osądzie rzeczywistości. Migracja w tym układzie jawi się jako kolejny problem destabilizujący w oczach Czechów Europę rozumianą jako wspólnotę, której się jest częścią. Inaczej trudno sobie wytłumaczyć miarę zaangażowania się w dyskusję o tym, czym Europa jest i czym nie jest.

Cytowany powyżej przykład nr 8 zmusza mnie do wyjścia poza pierwszych 5 miejsc frekwencyjnych w stworzonej przeze mnie liście. Na miejscu 9 z wynikiem frekwencyjnym 197 znalazła się bowiem lemma nieziskovky, która odnosiła się nie tylko do kwestii działających w basenie Morza Śródziemnego organizacji pozarządowych, ale również do szeroko rozumianych działań charytatywnych. W badanym materiale tekstowym bardzo wyraźna jest niechęć do tego rodzaju działań i instytucji. Uczestnicy dyskusji nie ukrywają swych podejrzeń, wedle których organizacje pozarządowe mają ukryte motywy działań, które można określić mianem motywacji finansowych:

[15] Dnes si paseraci lidi rikaji honosne 'neziskovky' a namisto par jedincu prevazi lidi po stovkach. A to vse beztrestne, za necinneho prohlizeni vlad postizenych zemi a s financnimi prispevky naivnich lidi, kteri si mysli, ze pomahaji dobre veci.

[16] To se Bruselu moc libit nebude....neziskovky na to dostavaji z EU silene dotace, a nejaky italsky ministr jim takto kazi jejich plany

[17] Bussines s lidmi z Afriky asi konci. Dobre, Italie, moc dobre. Neziskovky a vyrobci gumovych clunu musi zmenit predmet podnikani. 
[18] Jakoze bud jsou sami paseraci, nebo paserakum pomahaji. Maji status neziskovky a nepruhledne financovani.

W świetle takich przykładów wypada stwierdzić, że dla Czechów jednym z zasadniczych problemów związanych z kwestią migracji jest wynikające ze spiskowej teorii przekonanie, że organizacje pozarządowe zarabiają na kryzysie migracyjnym. Przekonanie to wydaje się być dla czeskich komentujących ważniejsze niż fakt, że kryzysowi migracyjnemu towarzyszą rzeczywiście bulwersujące zjawiska, takie jak choćby przemycanie ludzi.

W zestawieniu lemm leksemy związane $\mathrm{z}$ organizacjami pozarządowymi pojawiły się 197 razy, podczas gdy leksemy odnoszące się do polityki przemytu ludzi zaledwie 102 razy, co dało 39 pozycję na stworzonej na użytek badań liście słów odnoszących się do dyskursu czeskiego. Uderzające jest również, że w zestawieniach tych praktycznie w ogóle nie pojawiają się leksemy związane z Czechami. Wydaje się to przeczyć powszechnie przyjętej w czeskiej publicystyce przekonaniu, że Czesi rzeczywiście czują się zagrożeni jakimś niekontrolowanym napływem migrantów na teren Republiki Czeskiej. W zebranym materiale tekstowym znacznie częściej pojawiało się odwołanie do Niemiec, a w niektórych wypadkach kwestia Niemiec jako państwa była powiązana z kwestią państwowości czeskiej:

[19] Spise docili tlakem na Nemecko presunu dale do Nemecke EU, tedy i do Cr.

\section{Analiza polskiego materiału tekstowego}

Jak zatem na tle czeskim prezentuje się polski dyskurs? W pierwszym rzędzie zauważamy znaczące różnice ilościowe. Wynika to zapewne $\mathrm{z}$ faktu, że w analogicznym okresie monitorowania na łamach serwisu gazeta.pl pojawily sie trzy, a nie cztery jak to miało miejsce w wypadku serwisu czeskiego, teksty odredakcyjne. Co za tym idzie, na łamach polskiego serwisu pojawiło się mniej komentarzy. Oznacza to też, że - przynajmniej do pewnego stopnia - korpusowa analiza statystyczna bedzie miała większy margines błędu. Drugim efektem jest swego rodzaju spłaszczenie wyników statystycznych wynikających z polskiego materiału tekstowego. W wypadku tekstów czeskich $\mathrm{w}$ analizie frekwencyjnej wspartej listą lemmantyczną i stop-listą otrzymałam wyniki od 270 do ponad 600 dla pierwszych pięciu pozycji z listy frekwencyjnej. W przypadku tekstów polskich ilości wskazań dla pierwszej piątki wahają się w przedziale od 34 do 70. Można oczywiście poddać $\mathrm{w}$ wątpliwość wnioski wyciągnięte $\mathrm{w}$ oparciu o tak małą próbkę. $Z$ drugiej jednak strony jest to również pewna informacja - polscy użytkownicy kwestią migracji nie interesują się najwyraźniej aż tak bardzo jak czescy.

Analiza polskiego materiału tekstowego od strony metodologicznej przebiegała w ten sam sposób, co tekstów czeskich. Rozszerzeniu uległa stop-lista, podczas gdy lista lemmatyczna wyglądała dość podobnie. Polska stop lista prezentuje się następująco: a, albo, ale, bę$d z i e, b o, c i, c o, c z y, d l a, d n i, d o, i, i c h, i m, j a k$, jest, jeszcze, już, ma, maja, miesiaca, może, na, nawet, nie, niech, no, o, oceniono, od, odpowiedz, odpowiedzi, pawel, po, pol, przez, razy, rikol, sa, się, sobie, tak, tam, te, tego, temu, ten, teraz, tez, to, tych, tylko, tym, ukryj, w, z, za, ze. Przy układaniu listy lemmatycznej starłam się trzymać takich samych kryteriów jak w wypadku listy czeskiej, choć oczywiście jak zawsze w wypadku arbitralnych decyzji, mogą one zostać poddane w wątpliwość. Również jednak w wypadku listy polskiej chodziło mi zarówno o uzyskanie przejrzystości wyników jak i o zgrupowanie tematyczne w rodzaj pól semantycznych. Oto lista:

europa $\rightarrow$ [europa] [europie] [ue] [europy] [europejskie] [europejskich] [europejskiej] [europejski]

organizacje $\rightarrow$ [organizacje] [organizacja] [organizacji] [pozarzadowe] [ngo]

migranci $\rightarrow$ [migrantow] [migranci] [uchodzcow] [uchodzcami] [imigrantow]

statek $\rightarrow$ [statek] [statku] [statki] [aquarius] [lodzie] [aquariusa]

wloch $\rightarrow$ [wloch] [wlochy] [wloszech] [wlochow] [wlosi]

niemcy $\rightarrow$ [niemcy] [merkel] [niemczech]

soros $\rightarrow$ [soros] [sorosa]

afryka $\rightarrow$ [afryki] [afryka] [afryce] [afrykanskich] [afrykanskie]

polska $\rightarrow$ [polacy] [polakiem] [polakom] [polakow] [polakowi] [polsce] [polska] [polske] [polski] [polskich] [polskiego] [polsko] [polskiej] 
Lista frekwencyjna słów po zastosowaniu powyższych narzędzi wyglądała następująco:

europa - rank: 1 , freq. 82

migranci - rank: 2 , freq. 74

statek - rank: 3 , freq. 74

wlochy - rank: 4 , freq. 61

organizacje - rank: 5 , freq. 57

Jak wynika z tego zestawienia, Polacy w tym samym mniej więcej zakresie trzymają się tematu dyskusji, co wynika z wysokiej wysokości wskazań dla wyrazów związanych bezpośrednio z tematem komentowanego artykułu. Chodzi o pola semantyczne zbliżone do tych, które pojawiły się w przypadku analizowania czeskiego materiału tekstowego. W efekcie powstają wyraźne pary w zebranym materiale tekstowym:

Evropa (rank 1) - Europa (poz 1)

Lod - (rank 2) - statek (rank 3 z tą samą ilością wskazań co rank 2)

Migranti (rank 3), - migranci (poz. 2 z tą samą ilościa wskazań co rank 3 )

Italie (rank 4) - wlochy (rank 4)

Afrika (rank 5) - Afryka (rank 6)

Europa w polskich komentarzach nie jawi się jako obszar idealny i pod tym względem językowy obraz świata polskich dyskutantów wydaje się być niemal taki sam jak Czechów:

[20] Zadajacych dachu nad glowa, wyzywienia, ubrania, ogrzewania, pradu, wody (o pieniadzach nie wspomne) i innych uslug, ktore kosztuja! A ich praca nie jest wiele warta i nam niepotrzebna. Europa nie wytrzyma takiego naporu ludzi, nie bedzie gdzie ich umiescic ani nie da sie wyzywic, zaopatrzyc.

[21] Europa nie moze przyjac calej nedzy Afryki.

[22] Najwidoczniej Europa jest jeszcze nie przygotowana na taka ilosc naukowcow, lekarzy i inzynierow. Trzeba unowoczesnic gospodarke, aby mogla wchlonac kolejne porcje nowoczesnych umiejetnosci. Przyjmowanie ich w tym momencie byloby nieodpowiedzialnym marnowaniem zasobow.

W wypadku polskich dyskusji częściej zdecydowanie pojawiał się wạtek własnej społeczności - czyli Polski i Polaków - skonfrontowanej z problemem migracji. W przeciwieństwie do sytuacji czeskiej, w polskich dyskusjach problem własnej społeczności pojawił się już na 7 pozycji mojej listy. Trudno jednak o jednoznaczne ocenienie, co o Polsce w kontekście kryzysu migracyjnego sądzą sami Polacy - na przeszkodzie staje tutaj zbyt mała próbka tekstu. Niektóre wypowiedzi wydają się być merytorycznymi wypowiedziami:

[23] Dziwne, ze w Polsce do dzis sie mowi, ze Francja nie chciala ginac za Gdansk, ale samemu nie chcielismy pomoc czlonkom Unii,ktorzy solidarnie wplacaja do budzetu to, z czego Polska solidarnie dostaje pieniadze.

[24] Wstyd byc w takim gangu-Polska wcale nie lepsza bierze udzial w tym gangsteryzmie ale jak trzeba ludziom pomoc to odwraca glowy.

Inne z kolei ograniczają się do wulgaryzmów prezentowanych przy użyciu takiej grafii, by programy kontrolujące nie zablokowały komentarza (pisownia oryginalna):

\section{[25] CALA POLSKA SPIEWA Z NAMI WYP\# DALAC Z UCHODZCAM}

Jedną z cech odróżniających oba szeregi jest nieco wyższa w wypadku tekstów polskich ilość wskazań odnoszących się do organizacji pozarządowych niż miało to miejsce w wypadku czeskim. Sposoby oceniania ich działalności są mniej więcej takie same. Również w polskim tekście pojawia się nieufność w stosunku do ich statusu i sposobów finansowania, co w jawny sposób nawiązuje do przekonania o ich spiskowym charakterze:

[26] Ktos musi te organizacje finansowac. Ciekawe kto i w jakim celu.

[27] Ci finasujacy te organizacje zajmujace sie przemtem ludzi (inaczej nie mozna tego nazwac) maja w tym prosty cel - wprowadzic chaos i rozbic Europe.

[28] Miedzynarodowa organizacja pozarzadowa, ciekawe. Ciekawe kto finansuje te organizacje i kto za tym stoi.

W wypadku polskich tekstów przekonanie o niejasnych powiązaniach finansowych wpływających na przebieg kryzysu migracyjnego jest podkreślone dodatkowo pojawieniem się elementów stereotypów czẹsto pojawiających się w sprawach o podłożu finansowym. Oto bowiem w polskim dyskursie o migrantach pojawia się George Soros. 
Miejsce 16 na liście frekwencyjnej zajęło bowiem związane amerykańskim biznesmenem węgierskiego pochodzenia proprium, będące zapewne w mniemaniu dyskutujących odpowiedzią na pytanie, kto za tym wszystkim (czyli finansowaniem organizacji pozarządowych) stoi:

[29] Soros, ktory wcale sie z tym nie kryje.

[30] Soros. Chodzi o stworzenie Europy, w ktorej rzadza korporacje, a obywatele nie maja nic do powiedzenia.

[31] Czy oni zdaja sobie sprawe, co teraz zrobi im Soros i jak ich obesra Wyborcza?

[32] Calkowita odpowiedzialnosc za dramat ofiar przemytnikow ponosi Soros - partner ideologiczny i biznesowy GW i totalnej opozycji oraz KE

Do tej samej kategorii zaliczyć wypada związane z uprzedzeniami antysemickimi komentarze odnoszące się do Izraela. Nie były one statystycznie znaczące, ale pojawiły się:

[33] Brawo! W Izraelu ich przyjma z otwartymi ramionami. To taki europejski kraj jakby ktos nie wiedzial:) Wygrali Eurowizje :)))

[34] Zapytajcie w Izraelu bo i tak wyglada ze zgubili.

[35] Europa musi przyjmowac imigrantow, w szczegolnosci muzulmanskich. Kto twierdzi inaczej, jest ksenofobem, rasista, zwolennikiem Putina. W tym wszystkim chodzi o to, aby odciazyc Izrael od potencjalnej inwazji.

Uwagę zwracają również $\mathrm{w}$ tym kontekście powiązanie Niemiec jako elementu spisku. W tym względzie opinie polskie są mniej racjonalne niż te czeskie:

[36] na kazdego migranta spoza Unii Europejskiej przyjetego po 2013 roku Niemcy otrzymaja 2800 euro rekompensaty. Wedlug danych Eurostatu Niemcy przyjely okolo 1,7 miliona migrantow.

Niemcy są też postrzegane przez polskich komentujących jako kraj stosujący nieuczciwe narzędzia w prowadzeniu polityki międzynarodowej. Konflikt polsko-niemiecki ma być wedle tych spiskowych wizji świata elementem ukrywającym prawdziwą naturę sporu prowadzonego w obrębie Unii Europejskiej:
[37] To nie z Polska Unia (a praktycznie Niemcy) maja najwiekszy problem. Polska to typowa przykrywka. Najwiekszy problem od kilku lat maja z Wlochami. Najpierw gigantyczne zadluzenie i deficyt budzetowy a teraz jeszcze dojdzie problem nachodzcow. Angela ma dwa wyjscia, albo przyzna ze ma problem z Wlochami albo dla przykrywki jeszcze bardziej zintensyfikuje nagonke na Polske.

\section{Wnioski}

Abstrahując od samego materiału tekstowego wypada zauważyć, że analiza komentarzy jako dyskursu może odbywać się nawet bez nich. Ta paradoksalna konstatacja związana jest z sytuacją serwisu Gazeta.pl, który zdecydował się wyłączyć możliwość komentowania w jednym ze swoich tekstów poświęconym migrantom. W oczywisty sposób okres żywiołowego rozwoju Internetu jako nowego medium komunikacyjnego się zakończył i zaobserwować można teraz tendencje do ograniczenia swobody wypowiedzi, czy też zachowań kolidujących z grzecznością językową jak ujęli by to inni. Żywiołowy rozwój badań typu big data nie ominął językoznawstwa i w tym sensie Internet do niedawna jawił się jako medium idealnie nadające się do zbierania olbrzymich ilości materiału tekstowego, który następnie można poddać ilościowym narzędziom analizy. Wyłączanie komentarzy pod niektórymi tekstami lub też całkowita rezygnacja z możliwości toczenia dyskusji na łamach stron internetowych niektórych gazet nakazuje swoisty pesymizm w tej kwestii. To wniosek natury ogólnej nie związany bezpośrednio z opracowywanym materiałem tekstowym.

Nawiązuje do niego spostrzeżenie, że biorący udział w sporach internetowych są bardziej przywiązani do tematu dyskusji narzuconego przez zinstytucjonalizowanego nadawcę niż by się dało oczekiwać. Brak niestety jakichkolwiek poważnych tekstów naukowych na temat gatunku internetowego jakim jest komentarz, ale chęć cenzurowania komentarzy wynikająca z przekonania, że toczone anonimowo w Internecie dyskusje nie sa wystarczająco merytoryczne, wydaje się stać w sprzeczności z otrzymanymi wynikami badań. Faktem jest, że 
w materiale tekstowym pojawiły się wyrażenia wulgarne, stanowiły one jednak margines. Analiza kolokacji wykazała, że toczona dyskusja dotyczyła komentowanego tekstu i nie przekształcała się wcale w agresywną kłótnię. Ten wynik stoi zresztą w sprzeczności z potocznymi wyobrażeniami o dyskusjach internetowych.

Wypada również stwierdzić, że wykorzystanie metod związanych $\mathrm{z}$ analizą dyskursu okazało się przydatnym narzędziem do ujednolicania wszystkich komentarzy w jeden tekst. Ten krok z kolei prowadził do nieoczywistych na wstępie konstatacji. Trudno bowiem było założyć na początku pracy, że zarówno czeskie jak i polskie komentarze będą niemal identyczne pod względem tematów pojawiających się w komentarzach. Zbieżność wyników czeskich i polskich analiz statystycznych związanych z listą słów i lemmami jest uderzająca. Chyba jeszcze bardziej zaskakuje, że w komentarzach tych najważniejszym tematem nie okazali się wcale migranci, ale sytuacja Europy - zarówno jako kontynentu jak i ponadnarodowej wspólnoty Unii Europejskiej. Analiza dyskursu okazała sie zatem przydatna w pokazywaniu tego co łączy czeskich i polskich dyskutantów internetowych, choć nie mogę nie przyznać się, że przed przeprowadzeniem badań oczekiwałam raczej, że wyraziściej będzie widać różnice a nie podobieństwa. W tym sensie można chyba mówić o tym, że pod względem językowym Internet ma rzeczywiście siłę unifikującą użytkowników różnych języków. Pomimo różnic w samych językach, użytkownicy mówią o tym samym i tym samym sposobem.

\section{Literatura}

D i j k T.A. van, 2001, Badania nad dyskursem, [w:] Dyskurs jako struktura i proces, red. T.A. van Dijk, thum. G. Grochowski, Warszawa.

D i j k J., 2010, Społeczne aspekty nowych mediów, thum. J. Konieczny, Warszawa: PWN.

Dyskurs i jego odmiany, 2016, red. B. Witosz, K. Sulejowska-Sobisz, E. Ficek, Katowice: Wydawnictwo Uniwersytetu Ślaskiego.

G o b a n Klas T., 2004, Media i komunikowanie masowe. Teorie i analizy prasy, radia, telewizji i Internetu, Warszawa: PWN.

Gri e s S., 2009, Quantitative Corpus Linguistic with R, New York: Routledge.
J a bł o ń s k a B., 2006, Krytyczna analiza dyskursu, „Przegląd Socjologii Jakościowej", tom II, nr 1, s. 53-67.

L a b o c h a J., Zaolziański dyskurs tożsamości etnicznej, [w:] Dyskurs i jego odmia$n y$, red. B. Witosz, K. Sulejowska-Sobisz, E. Ficek, Katowice: Wydawnictwo Uniwersytetu Śląskiego, 2016, s. 156-165.

Labocha J., Dyskurs jako proces przekazywania wiedzy, [w:] Dyskurs edukacyjny, red. T. Rittel, Kraków: Wydawnictwo WSP, s. 9-15.

L o e w e I., 2012, Internet i jego zasoby w polskich badaniach lingwistycznych, [w:] Język w mediach. Antologia, red. M. Kita, I. Loewe, Katowice: Wydawnictwo Uniwersytetu Śląskiego, s. 269-280.

S v o b o d o vá J., 2016, Manipulace a argumentace v politickém a mediálním diskurzu, Olomouc.

S z a c k i J., 2005, Historia myśli socjologicznej, Warszawa: PWN.

W i t o s z B., 2012, Badania nad dyskursem we współczesnym językoznawstwie polonistycznym, „Oblicza komunikacji”, nr 5, s. 61-76. 